\title{
Free Fibular Osteoseptocutaneus Flap for Reconstruction of Giant Ameloblastoma
}

\author{
Rachmat Wiardi, Irra R. W. \\ Department of Plastic Surgery \\ Faculty of Medicine,Padjadjaran University- Hasan Sadikin Hospital \\ Jl. Pasteur 38, Bandung 40161,Indonesia \\ Email:mamatowiardi@gmail.com
}

\begin{abstract}
Ameloblastoma is a tumor originating from odontogenic epithelial cells. The tumor is located in the gray zone between benign and malignant neoplasm. These tumors can occur at any age. Although traditionally divided as solid and cystic ameloblastoma, nearly all showed cystic changes. These tumors are invasive and have a very high recurrence rate. The operative therapy of choice is radical resection of the affected parts of the jaw, followed by reconstruction. Bridging titanium plate can be used to replace part of lost bone and serves as a means of reconstruction. Various methods of reconstruction of the mandible can be done by using a bone graft from the calcaneus, fibula, ribs, scapula, iliac crest, or flap reconstruction. We reported a case of a 18 years old male patient with lump under the tongue that emerged 8 years ago, accompanied by eating and speaking difficulty, and shortness of breath. The diagnosis of mandible ameloblastoma was confirmed by anatomical pathology examination. The patient went through segmental mandibulectomy and free fibular osteoseptocutaneous free flap with multiple osteotomy. Patients went home with improved condition.
\end{abstract}

Keywords: ameloblastoma, free fibular flap osteoseptocutaneus 


\title{
Free Fibular Osteoseptocutaneus Flap untuk Rekonstruksi Giant Ameloblastoma
}

\author{
Rachmat Wiardi, Irra R. W. \\ Departemen Bedah Plastik \\ Fakultas Kedokteran Universitas Padjadjaran / RSUP. Dr. HasanSadikin Bandung \\ J1. Pasteur 38, Bandung 40161, Indonesia \\ Email: mamatowiardi@gmail.com
}

\begin{abstract}
Abstrak
Ameloblastoma merupakan tumor yang berasal dari sel epitel odontogenik. Tumor ini terletak pada zona abu-abu antara neoplasma jinak dan ganas. Tumor ini dapat terjadi pada semua usia. Meskipun secara tradisional dibagi menjadi ameloblastoma solid dan kistik, hampir semua menunjukkan perubahan kistik. Tumor ini bersifat invasif dan memiliki tingkat rekurensi yang sangat tinggi. Terapi operatif terpilih adalah reseksi radikal dari bagian rahang yang terkena yang dilanjutkan dengan rekonstruksi. Bridging plate titanium dapat digunakan untuk mengganti sebagian tulang yang hilang dan berfungsi sebagai alat rekonstruksi. Berbagai metode rekonstruksi mandibula dapat dikerjakan dengan menggunakan graft dari tulang kalkaneus, fibula, kosta, skapula, krista iliaka, atau rekonstruksi flap. Kami melaporkan satu kasus penderita pria usia 18 tahun dengan keluhan timbul benjolan di bawah lidah sejak 8 tahun yang lalu, disertai sulit makan, sulit bicara, dan sesak nafas. Diagnosis ameloblastoma mandibula ditegakkan atas dasar pemeriksaan patologi anatomi. Pasien menjalani segmental mandibulektomi dan rekonstruksi free fibular osteoseptocutaneous free flap dgn multiple osteotomi. Pasien pulang dalam kondisi perbaikan.
\end{abstract}

Kata kunci: ameloblastoma, free fibular osteoseptocutaneus flap 


\section{Pendahuluan}

Ameloblastoma merupakan suatu tumor epitelial odontogenik yang berasal dari jaringan pembentuk gigi, bersifat jinak, tumbuh lambat, penyebarannya lokal invasif dan destruktif serta mengadakan proliferasi ke dalam stroma jaringan ikat. Tumor ini mempunyai kecenderungan untuk kambuh apabila tindakan operasi tidak memadai. Sifat yang mudah kambuh dan penyebarannya yang ekspansif dan infiltratif ini memberikan kesan ganas dan oleh karena sifat penyebarannya maupun kekambuhannya lokal maka tumor ini sering disebut sebagai locally malignancy. ${ }^{1}$

Etiologi ameloblastoma sampai saat ini belum diketahui dengan jelas, tetapi beberapa ahli mengatakan bahwa ameloblastoma dapat terjadi setelah pencabutan gigi, pengangkatan kista dan atau iritasi lokal dalam rongga mulut. ${ }^{2,3}$ Patogenesis dari tumor ini, melihat hubungan dengan jaringan pembentuk gigi atau sel-sel yang berkemampuan untuk membentuk gigi tetapi suatu rangsangan yang memulai terjadinya proliferasi selsel tumor atau pembentuk ameloblastoma belum diketahui. ${ }^{4,5}$ Shafer et $\mathrm{al}^{2}$ mengemukakan kemungkinan ameloblastoma berasal dari sumber-sumber sisa sel organ enamel (hertwig's sheat, epitel rest of mallassez), gangguan pertumbuhan organ enamel, epitel dinding kista odontogenik terutama kista dentigerous dan sel epitel basal permukaan rongga mulut. $^{2}$

Ameloblastoma dapat terjadi pada segala usia, namun paling banyak dijumpai pada usia dekade 4 dan 5 . Tidak ada perbedaan jenis kelamin, tetapi predileksi pada golongan penderita kulit berwarna. Ameloblastoma dapat mengenai mandibula maupun maksila, paling sering pada mandibula sekitar 81\%-98\%, predileksi di daerah mandibula $60 \%$ terjadi di regio molar dan ramus, $15 \%$ regio premolar, dan $10 \%$ regio simfisis. ${ }^{2,3,5,6}$

Gambaran klinik dalam tahap awal jarang menunjukkan keluhan, oleh karena itu tumor ini jarang terdiagnosa secara dini, umumnya diketahui setelah 4 sampai dengan 6 tahun. ${ }^{3,6,7}$ Pembengkakan dengan berbagai ukuran yang bervariasi sehingga dapat menyebabkan deformitas wajah, warna sama dengan jaringan sekitarnya, konsistensi bervariasi ada yang keras dan kadang ada bagian yang lunak, berbatas tegas, terjadi ekspansi tulang ke arah bukal dan lingual, tumor ini meluas ke segala arah mendesak dan merusak tulang sekitarnya, terdapat tanda egg shell cracking atau pingpong ball phenomena bila massa tumor telah mendesak korteks tulang dan tulangnya menipis, 


\section{Case Report}

tidak ada rasa nyeri dan tidak ditemukan parestesi, mukosa sekitas tumor tidak mengalami ulserasi. Hanya pada beberapa penderita benjolan disertai rasa nyeri, berkurangnya sensibilitas daerah distribusi n.mentalis dan kadang-kadang terdapat ulserasi oleh karena penekanan gigi apabila tumor sudah mencapai ukuran besar. ${ }^{1,3}$ Gigi geligi pada daerah tumor berubah letak dan goyang. Bila terjadi infeksi sekunder maka ulserasi, fistula bahkan jaringan granulasi pun dapat dijumpai, demikian juga rasa nyeri, parestesi, dan tanda-tanda inflamasi. ${ }^{1,3}$

Gambaran radiologis berupa lesi unilokuler atau multilokuler dengan gambaran seperti sarang tawon (honey comb appearance) pada lesi yang kecil dan gambaran busa sabun (soap bubble appearance) pada lesi yang besar. Hal ini merupakan proses osteolitik, karena ameloblastoma tumbuh secara lambat, secara radiologis tepinya berbatas jelas halus, corticated dan curved, terdapat resorpsi akar dan bergesernya gigi jauh dari tempat asal. ${ }^{8}$ Menurut gambaran radiologis ameloblastoma dibagi menjadi 3, yaitu konvensional solid/multikistik (86\%), unikistik (13\%) dan ekstra osseous $(1 \%){ }^{5}$ Computed tomografi (CT-scan) memberikan gambaran anatomi dari potongan jaringan secara 2 dimensi dan 3 dimensi dengan akurat. Keuntungan dari teknik ini yaitu tidak terjadi gambaran yang tumpang tindih dan memberikan gambaran jaringan secara detil dari perusahaan daerah yang terlibat. ${ }^{9}$

Shafer et $\mathrm{al}^{2}$ membedakan gambaran histopatologis dari ameloblastoma menjadi folikuler, pleksiform, acantomatous, granuler dan sel basal. Secara hisptopatologis, terdapat pulau-pulau epitel atau lembaran yang bagian luar dilapisi sel-sel kolumnar, pada bagian tengah ditemukan sel stelat yang menyerupai stelat retikulum dari enamel organ dan stroma terdiri dari jaringan ikat fibrosa. Gambaran histopatologi pada ameloblastoma, dapat hanya satu jenis saja atau dapat terdiri dari berbagai jenis pola. Yang paling sering ditemukan adalah tipe folikuler dan pleksiform. ${ }^{1,2,3}$

Ameloblastoma mandibula dapat memperlihatkan gambaran klinis dan radiografis yang mirip dengan kelainan lain pada mandibula. Sebagai diagnosis banding adalah osteosarkoma, calcifying ephitelial odontogenik tumor, ossifying fibroma, dan kista dentigerus. ${ }^{10}$ Penatalaksanaan yang tepat masih diperdebatkan. Tingkat rekurensi berkisar antara $55-90 \%$ setelah perawatan secara konservatif. ${ }^{1,3}$ Mengingat besarnya tingkat rekurensi tersebut, pendekatan secara radikal (reseksi) dapat dipertimbangkan 
sesuai indikasi, meskipun berakibat hilangnya sebagaian tulang rahang. Bridging plate titanium dapat digunakan untuk mengganti sebagian tulang yang hilang dan berfungsi sebagai alat rekonstruksi. Dapat juga dilakukan rekonstruksi dengan menggunakan tulang kalkaneus, fibula, kosta, skapula maupun krista iliaka. ${ }^{1,3}$

Indikasi operasi berdasarkan luas dan besarnya jaringan yang terlibat, struktur histologis dari tumor dan keuntungan yang didapat. ${ }^{6,11}$ Menurut Ohishi, indikasi perawatan konservatif adalah pada penderita usia muda dan ameloblastoma unikistik. Indikasi perawatan radikal adalah ameloblastoma tipe solid dengan tepi yang tidak jelas, lesi dengan gambaran soap bubble, lesi yang tidak efektif dengan penatalaksanaan secara konservatif dan ameloblastoma ukuran besar. Penatalaksanaan secara radikal berupa reseksi segmental, hemimandibulektomi, dan reseksi marginal (reseksi enblok). ${ }^{12}$

Reseksi marginal (reseksi enblok) merupakan teknik untuk mengangkat jaringan tumor dengan mempertahankan kontinuitas korteks tulang mandibula bagian bawah yang masih intak. Reseksi enblok ini dilakukan secara garis lurus dengan bor dan atau pahat atau gergaji, 1 - $2 \mathrm{~cm}$ dari tepi batas tumor secara rontgenologis yang diperkirakan batas minimal reseksi. Tindakan dapat dilakukan secara intra maupun ekstra oral, hal ini tergantung pada seberapa besar untuk mendapat eksposure yang adekuat sampai ke ekstensi tumor. ${ }^{11,12}$

Rekontruksi mandibula ditinjau dari fungsi dan kosmetik, organ ini mempengaruhi bentuk wajah, fungsi bicara, mengunyah dan menelan. Beberapa cara dapat dipakai antara lain menggunakan bahan aloplastik, misalnya bridging plate titanium dan autogenous bone grafting misalnya tandur tulang iga, krista iliaka dan tibia serta dapat juga secara kombinasi aloplastik material dengan autogenous bone grafting. ${ }^{12}$

Flap merupakan suatu unit jaringan yang dipindahkan dari satu area (donor site) ke area yang lain (recipient site) dengan masih mempertahankan sistem aliran darahnya sendiri. ${ }^{13}$ Flap kulit dapat diambil dengan berbagai cara dan bentuk dalam rangka menutup defek jaringan yang ada pada daerah resipien. Flap kulit digunakan sebagai penutup luka saat kemampuan vaskuler dari dasar luka dianggap tidak mencukupi kebutuhan yang diperlukan pada skin graft ${ }^{13}$ 
Skin flap dapat diklasifikasikan berdasarkan: anatomi vaskularisasinya, metoda penggunaannya, komponen jaringannya. Berdasarkan anatomi vaskularisasinya skin flap diklasifikasikan menjadi axial pattern flap, neurocutaneus flap, musculocutaneus flap. Berdasarkan metode penggunaannya skin flap diklasifikasikan menjadi free flap, peninsular flap, dan island flap. Free flap memiliki ukuran bervariasi, termasuk di dalamnya kulit, otot, fascia dan tulang, benar-benar dilepaskan dari aliran darah asalnya, membutuhkan anastomose secara mikrosurgikal. Peninsular flap memiliki ciri khas adanya pedikel kutaneus di proksimal maupun distal, dapat digunakan sebagai rotasional flap, dan terbatas dalam kemampuannya menutup defek. Island flap memiliki ciri khas adanya vaskular pedikel, pedikel terdiri dari arteri, dan sebagian vena comitantes dikelilingi oleh jaringan seluler. Berdasarkan komponen jaringannya, skin flap diklasifikasikan menjadi fascial flap,subcutaneus flap, cutaneus flap, dan fasciocutaneus flap.

Pada fascial flap, fascia dalam dan lapisan tipis subkutaneus digunakan sebagai pelindung jaringan suprafascial plexiform. Pada subcutaneus flap dilakukan diseksi antara lapisan subdermal dan suprafascial dan merupakan vaskularisasi dengan pola axial. Pada cutaneus flap lapisan diseksi berada di atas permukaan fascia superficial atau aponeurosis muscular (contoh groin flap atau scapular flap). Fasciocutaneus flap, di angkat secara en blok termasuk di dalamnya kulit, jaringan subkutaneus, dan fascia dalam.

Terdapat beberapa indikasi untuk dilakukan free flap pada pembedahan rekonstruksi, antara lain terdapatnya defek yang menyebabkan tulang, pembuluh darah, jaringan otak, persendian atau implant nonbiologi yang terpapar kepada dunia luar. ${ }^{14}$

Perawatan pasca operasi reseksi enblok mandibular dilakukan dengan pemberian medikasi antibiotik dan analgetik, tidak perlu dilakukan intermaksila fiksasi. Hindarkan trauma fisik pada muka atau rahang karena dapat menyebabkan fraktur mandibula. Jaga oral hygiene hingga luka operasi sembuh sempurna. Diet lunak dipertahankan 4-6 minggu. Jika diperlukan dapat dibuatkan prostesis gigi setelah dipertimbangkan bahwa telah terjadi internal bone remodeling tulang mandibula, lebih kurang 6 bulan pasca operasi. $^{15}$ 
Case Report

Laporan kasus ini sudah mendapat ijin oleh penderita sendiri dan disetujui oleh komite medik Rumah Sakit Hasan Sadikin Bandung. Seorang laki-laki berusia 18 tahun datang berobat ke Rumah Sakit Hasan Sadikin Bandung pada tanggal 11 Mei 2010 datang dengan keluhan adanya benjolan di bawah lidah yang timbul sejak 8 tahun yang lalu, mulanya sebesar kelereng, makin lama makin membesar hingga sebesar kepalan tangan orang dewasa. Sekitar 6 bulan yang lalu, benjolan pecah dan sedikit mengecil namun membesar kembali hingga pasien mengeluhkan adanya kesulitan makan dan bicara serta sesak nafas. Keluhan tidak disertai penurunan berat badan.

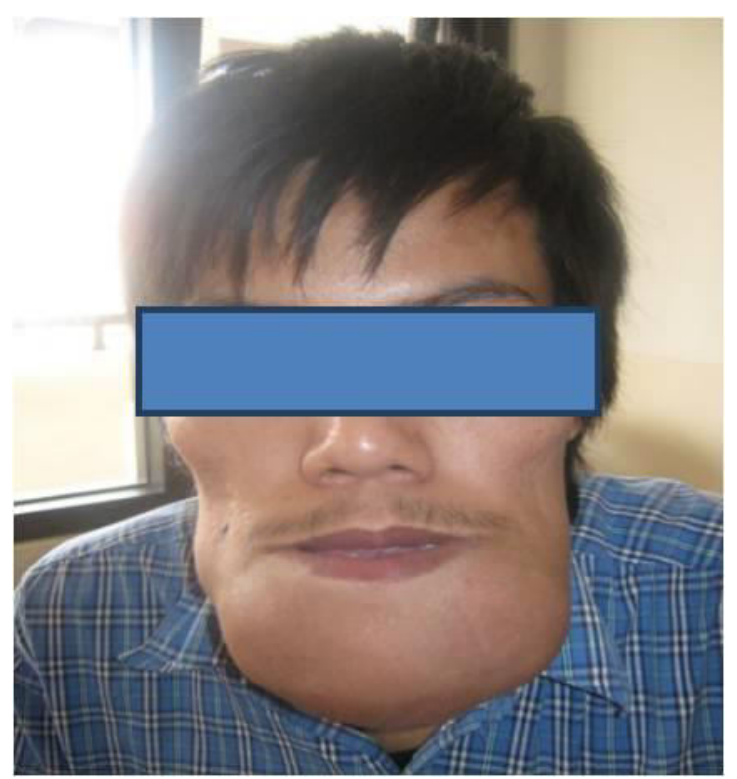

Gambar 1 Foto klinis pada pasien

Dari pemeriksaan fisik didapatkan status generalis dalam batas normal. Pada status lokalis didapatkan massa dengan konsistensi sebagian solid dan sebagian kistik dengan ukuran $15 \times 10 \mathrm{~cm}$, terfiksir, tidak didapatkan nyeri tekan. Dari pemeriksaan laboratorium didapatkan hasil $\mathrm{Hb}$ : 11.2, Leukosit: 9.800, trombosit: 163.000, hematokrit: 33, ureum: 31, kreatinin: 0.73, natrium: 134, kalium: 4,3.

Hasil rontgen panoramik memperlihatkan adanya gambaran multilokuler dari M2 kanan bawah sampai dengan M3 kanan bawah. 
Dari pemeriksaan patologi anatomi didapatkan hasil sediaan dilapisi epitel gepeng berlapis yang akantosis. Inti sel dalam batas normal. Stroma tampak massa tumor yang terdiri dari sel bentuk bulat sampai spindle yang tumbuh hiperplastis membentuk pulau-pulau dengan bagian tengah yang hiperseluler dan ditemukan juga sel bentuk stellate. Inti sel dalam batas normal. Disekitarnya tampak sebukan masif sel radang limfosit, sel polimorfonuklear $(\mathrm{PMN})$ dan perdarahan. Tidak tampak tanda ganas. Kesimpulan dari pemeriksaan tersebut adalah ameloblastoma dengan peradangan non spesifik pada mandibula.

Berdasarkan diagnosis kerja ameloblastoma mandibula diputuskan untuk dilakukan segmental madibulektomi dengan free fibular osteoseptocutaneous free flap dan multiple osteotomy dengan Split Thicknes Skin Graft (STSG) pada daerah fibula.

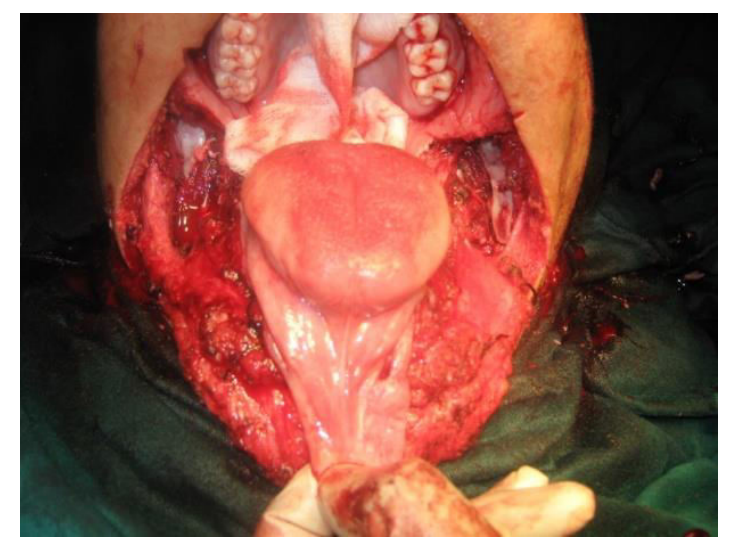

Gambar 2 Foto Intraoperatif pada Mandibula

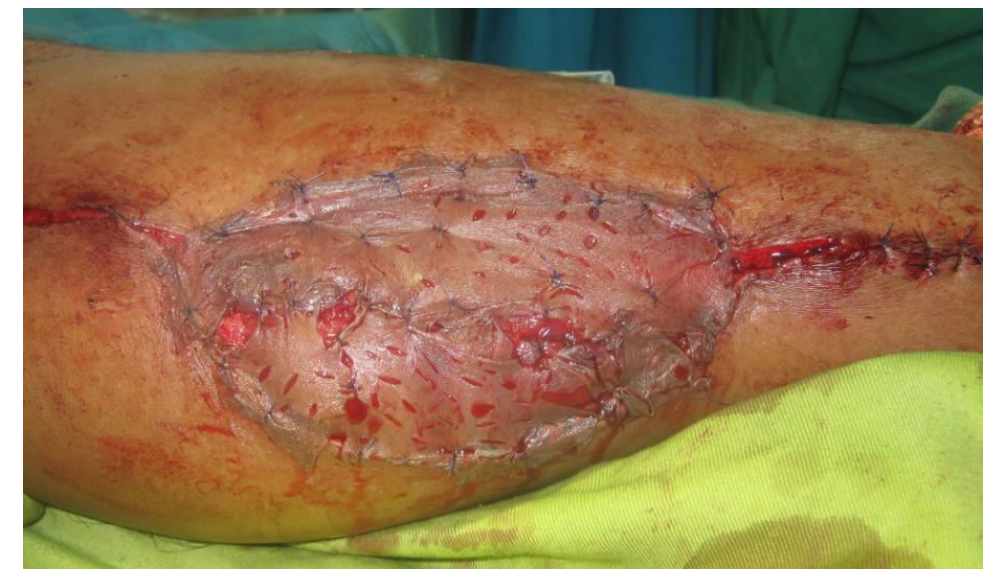

Gambar 3 Foto Intraoperatif Split Thicknes Skin Graft (STSG) pada Daerah Fibula 
Case Report

Saat tindakan operasi oleh bagian Bedah Onkologi ditemukan massa tumor yang terdapat mulai dari angulus mandibular kiri sampai angulus mandibular kanan, berbatas tegas, berisi cairan jernih bersepta-septa, dan memiliki dinding tipis dan rapuh, dan selanjutnya dilakukan segmental mandibulektomi.

Saat tindakan operasi oleh bagian Bedah Plastik ditemukan defek mandibular dengan ukuran $1 \mathrm{~cm}$ di atas angulus mandibula sinistra sampai dengan $1 \mathrm{~cm}$ di atas angulus mandibular dekstra. Angulus, korpus dan parasimfisis, simfisis kanan dan kiri dari mandibula dibuang. Diagnosis kerja pascaoperasi adalah ameloblastoma pada mandibula yang telah dilakukan segmental mandibulektomi dengan free fibular osteoseptocutaneous free flap dan multiple osteotomi dengan Split Thicknes Skin Graft (STSG).

Pasien kemudian diperbolehkan pulang dengan keadaan perbaikan setelah dirawat selama 2 bulan dan disarankan kontrol teratur ke Bagian Bedah Plastik Rumah Sakit Hasan Sadikin Bandung. 


\section{Case Report}
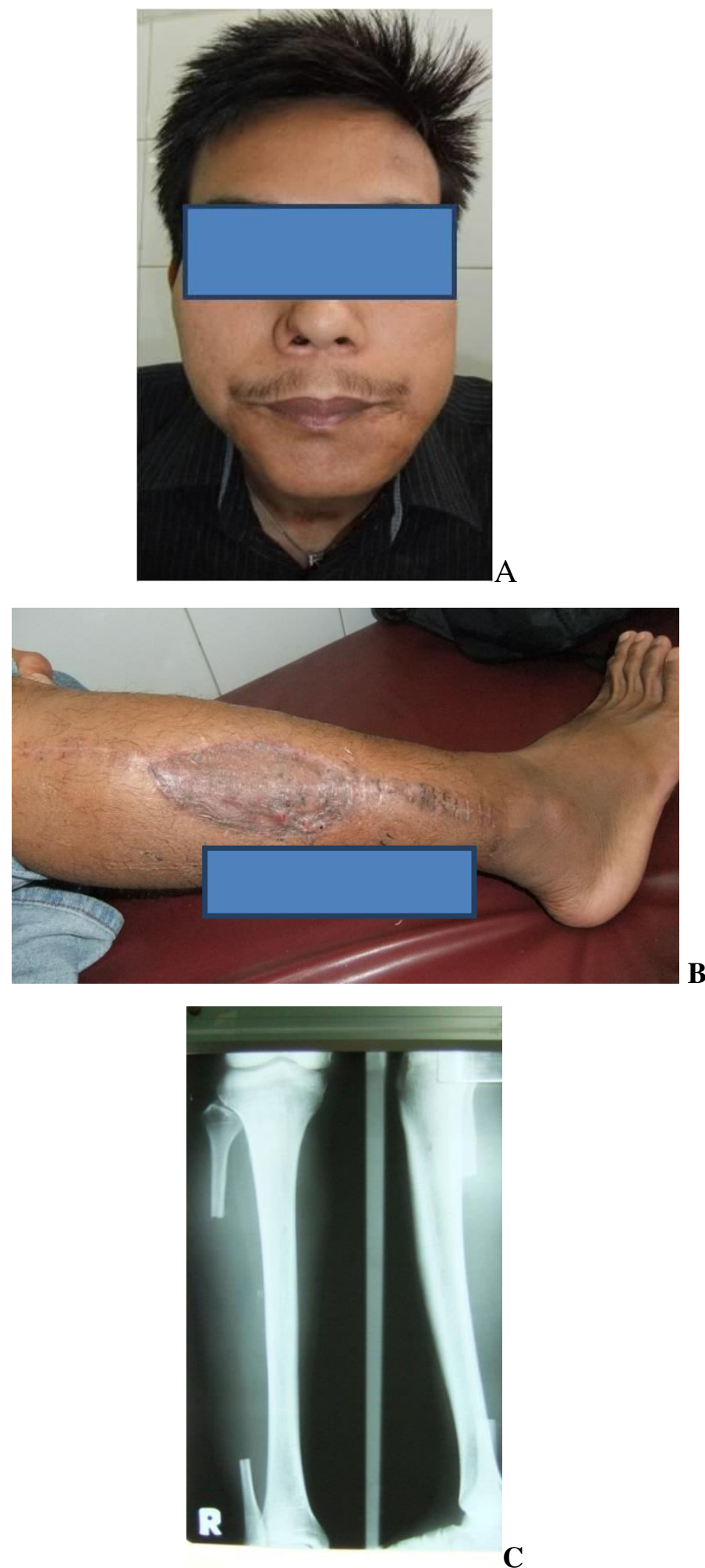

Gambar 4 Kondisi Klinis Pascaoperasi. A. Pada Wajah Pasien. B. Pada Daerah Fibula Tempat Thicknes Skin Graft (STSG). C. Gambaran Rontgen pada Fibula. 


\section{Diskusi}

Indikasi operasi pada kasus ini dilakukan berdasarkan luas dan besarnya jaringan yang terlibat, struktur histologis dari tumor, dan keuntungan yang didapat. Menurut Ohishi $^{12}$, indikasi perawatan konservatif adalah pada penderita usia muda dan ameloblastoma unikistik, sedangkan indikasi perawatan radikal adalah ameloblastoma tipe solid dengan tepi yang tidak jelas, lesi dengan gambaran soap bubble, lesi yang tidak efektif dengan penatalaksanaan secara konservatif dan ameloblastoma ukuran besar. Penatalaksanaan secara radikal yang dapat dilakukan berupa reseksi segmental, hemimandibulektomi dan reseksi marginal (reseksi enblok) yang melibatkan reseksi pada bagian rahang yang terkena tumor dan mengikutkan sekitar 1 sampai $2 \mathrm{~cm}$ dari tulang yang sehat.

Indikasi dilakukannya free flap pada pasien ini adalah terdapatnya defek yang menyebabkan tulang, pembuluh darah, dan persendian terpapar kepada dunia luar. Penatalaksanaan pada pasien ini adalah reseksi segmental dan keputusan ini dibuat berdasarkan indikasi ameloblastoma dengan jaringan yang terlibat luas dan ukuran yang besar, dari gambaran radiologis yang multilokuler.

Plat rekonstruksi mandibula memiliki keuntungan yaitu tidak membutuhkan donor, kontur yang baik, kemampuan untuk membentuk kondilus, tidak membuat luka baru pada bagian tubuh lain. ${ }^{16}$ Walaupun demikian plat rekonstruksi mandibula memerlukan biaya yang mahal. Komplikasi yang umum terjadi meliputi ekstrusi atau expose plat, kehilangan sekrup, fraktur plat, osteomyelitis. ${ }^{16}$

Graft merupakan suatu bagian jaringan yang diambil dari satu tempat dan ditransplantasikan ke tempat lain, baik pada individu yang sama maupun yang berlainan. Tujuannya untuk memperbaiki cacat yang disebabkan oleh penyakit, kecelakaan, atau anomali pertumbuhan dan perkembangan. Bone graft merupakan pilihan yang banyak digunakan untuk memperbaiki kerusakan tulang periodontal. Dengan graft tulang diharapkan terjadi perbaikan klinis pada tulang periodontal, hal ini lebih baik bila dibandingkan dengan cara bedah pembersihan biasa tanpa penambahan bahan graft. $^{17}$ Terdapat dua fungsi utama graft terhadap tulang resipien yaitu mendorong terjadinya osteogenesis (pembentukan tulang) dan memberi dukungan mekanis pada kerangka resipien (mechanical support). Fungsi graft dan tulang untuk 
Case Report

mendorong osteogenesis dapat melalui 3 cara. Mekanisme yang pertama adalah pembelahan sel; sel dipermukaan graft dan tulang yang masih hidup pada saat dipindahkan selanjutnya membelah diri dan membentuk tulang baru. Hal ini dapat terjadi pada cancelous autograft dan fresh cortical graft. Mekanisme yang kedua adalah osteoinduksi, yaitu merupakan proses menarik sel pluripotensial dari resipien yang terdapat disekitar graft dan tulang. Hal ini terjadi karena graft dan tulang mengandung mediator osteoinduksi, seperti BMP (Bone Morphogenic Protein), merupakan matrik tulang sehingga aktivitasnya tidak dipengaruhi oleh ada tidaknya sel tulang yang hidup, tidak dirusak oleh freezing tetapi rusak oleh oktoklaf. BMP terdapat pada autograft, allograft, dan fresh bone, merupakan glikoprotein, dimana protein ini aktif pada demineralized bone matriks. Mekanisme yang ketiga adalah osteokonduksi, yaitu proses resorpsi graft yang kemudian diganti oleh tulang baru dari respien secara bertahap. Konstribusi graft dimulai dengan proses osteokonduksi yaitu membuat kerangka sebagai matriks tulang di jaringan resipien, dilanjutkan dengan stimulasi pembentukan tulang sebagai proses osteoinduksi.

Keuntungan rekonstruksi dengan bone graft adalah berasal dari jaringan tubuh sendiri, tetapi mempunyai beberapa kekurangan yaitu jumlahnya terbatas, sulit mengambil material graft, meningkatkan resiko infeksi, menambah waktu operasi meningkatkan resiko kehilangan darah dan menambah waktu anestesi, menyebabkan morbiditas serta kemungkinan resorbsi akar pada daerah donor. ${ }^{17}$

Pada kasus ini setelah dilakukan tindakan dan perawatan selama 2 bulan, pasien mengalami perbaikan dan diperbolehkan pulang. Rencana selanjutnya yang akan dilakukan adalah pembuatan protesis gigi atau implant gigi oleh Bagian Bedah Mulut.

\section{Daftar Pustaka}

1. Neville BW, Damn DD, Alen CM, Boiqout JE. Oral and maxillofacial pathology. Philadelphia: WB Sauders Co; 1995.

2. Shafer GS, Hine MR, Levy BM. A text book of oral pathology, 4thed. Philadelphia: WB Sauders Co; 1983.p.276-85.

3. Thoma KH. Oral Pathology 2nd ed, Vol 1. St.Louis: Mosby Co; 1970.p.481-9

4. Bhaskar SN. Synopsis of oral pathology 6th ed. London: Mosby Co: 1981.p.220-6,252-6,

5. Regezi JA, Sciuba JJ. Oral pathology clinical pathology correlation. Philadelphia: WB Sauders Co; 1989.p.3379.

6. Laskin DW. Oral and maxillofacial Surgery, Vol II. St.Louis: CV Mosby; 1974.p.568-70

7. Archer WH. Oral and maxillofacial surgery, 5th ed, Vol.1. Philadelphia: WB Sauders Co; 1975.p.735-59

8. Farman AG, Nortje CJ, Wood RE. Oral and maxillofacial diagnostic imaging. St Louis: CV Mosby Co; 1993.p.239-43 


\section{Case Report}

9. Rothman SLG. Dental application of computed tomography. Quintessence Publishing Inc; 1998.p.156-7

10. Killey SK. An outline of oral surgery, part II. bristol: John Wright \& Sons Ltd; 1975.p.99-114.

11. Kruger GO. Text book of oral surgery, 4th ed. St. Louis:The Mosby co; 1974.p.568-70.

12. Ohishi M. Management of mandibula ameloblastoma the clinical basis for tratment alogaritm. J Oral Maxillofacial Surgery 1999:37.

13. Townsend, Courtney M. Sabiston textbook of surgery: 16th edition. Philadelphia:Saunders, 2001.

14. Huang D, Wang Hai-wen; Reconstruction of soft tissue defect of the extremity with the perforator flap from inguinal region. Chinese medical journal; 2009;122 (23);2861-64.

15. Keith DA. Atlas of oral and maxillofacial surgery. WB Sauders and co; 1992.p.99-101.

16. Dietrich T, Dibart S. Practical periodontal diagnosis and treatment planning. Wiley Blackwell: 100.

17. Kamran H. Dental implants. Dalam: Perry DA, Beemsterboer PL, penyunting. Periodontology for the dental hygienist. 3rd ed. St Louis: Missouri, 2007:320-49. 